\title{
Residential Mobility of a Cohort of Homeless People in Times of Crisis: COVID-19 Pandemic in an European Metropolis
}

\author{
Agathe Allibert 1,2, Aurélie Tinland ${ }^{3,4}$, Jordi Landier ${ }^{1}$, Sandrine Loubière 5,4, Jean Gaudart ${ }^{5}$, Marine Mosnier 6 , Cyril \\ Farnarier ${ }^{7}$, Pascal Auquier ${ }^{4}$ and Emilie Mosnier ${ }^{3,4 *}$ \\ 1 Aix Marseille Univ, INSERM, IRD, SESSTIM, Sciences Economiques \& Sociales de la Santé \& Traitement de \\ l'Information Médicale, ISSPAM, F-13005 MarseilleAix-Marseille University, INSERM, IRD, SESSTIM, \\ Sciences Economiques \& Sociales de la Santé \& Traitement de l'Information Médicale, F-13005 Marseille \\ 2 Epidemiology of Zoonoses and Public Health Research Unit (GREZOSP), Faculty of Veterinary Medicine, \\ Université de Montréal, Saint-Hyacinthe, Québec, Canada \\ 3 Department of Psychiatry, Assistance Publique - Hôpitaux de Marseille, F-13385 Marseille \\ 4 Aix-Marseille University, School of medicine - La Timone Medical Campus, EA 3279: CEReSS - Health \\ Service Research and Quality of Life Center, F-13005 Marseille \\ 5 Department of Clinical Research and Innovation, Support Unit for clinical research and economic evalua- \\ tion, Assistance Publique - Hôpitaux de Marseille, F-13385 Marseille \\ 6 Medecins du Monde - Doctors of the World, F-13003 Marseille \\ 7 LASSA/ASSAB \\ * Correspondence: emilie.mosnier@gmail.com; Tel.: +33 651532462
}

\begin{abstract}
Most vulnerable individuals are particularly affected by the COVID-19 pandemic. This study takes place in a large city in France. The aim of this study is to describe the mobility of the homeless population at the beginning of the health crisis and to analyze its impact in terms of COVID-19 prevalence. From June to August 2020 and September to December 2020, 1272 homeless people were invited to be tested for SARS$\mathrm{CoV}-2$ antibodies and virus in and completed questionnaires. Our data show that homeless populations are sociologically different depending on where they live. We show that people living on the street were most likely to be relocated to emergency shelters than other inhabitants. Some neighborhoods are points of attraction for homeless people in the city while others emptied during the health crisis, which had consequences for virus circulation. People with a greater number of different dwellings reported became more infected. This first study of the mobility and epidemiology of homeless people in time of pandemic provides unique information about mobility mapping, sociological factors of this mobility, mobility at different scales and epidemiological consequences. We suggest that homeless policies need to be radically transformed since actual model exposes people to infection in emergency.
\end{abstract}

Keywords: SARS-CoV2, COVID-19, homeless people, public health, vulnerable population, Seroprevalence, cohort, residential mobility.

\section{Introduction}

On March 11, 2020, the COVID-19 epidemic was declared a pandemic by the WHO [1]. By the end of 2020, it was estimated that the pandemic had already affected more than 173 million people worldwide and killed more than 3 million people [2]. The consequences of this crisis are also economic and social, particularly affecting the most vulnerable people [3]. Two recent French studies have shown that homeless people are at greater risk of SARS-CoV-2 infection than the general population [4, 5]. Homeless people have suffered from the disruption of their living and collecting places due to the epidemic. NGOs and the French public authorities took measures to help homeless people and provide them with shelter, especially during the initial confinement. Conversely, emerging data have shown that homeless people living on the street appear to be at lower risk of SARS-CoV-2 infection than people living in shelters $[3,4,6]$. This observation may be due to asymptomatic infections, which account for approximately $17 \%$ of cases [7]. The problem of asymptomatic infection is particularly important in congregate shelters, as asymptomatically infected persons can unknowingly transmit the infection to a large number of 
people in a short period of time [7]. Disrupted mobility may also play a role in the patterns of SARS-CoV-2 infection in the homeless population. Indeed, the impact of mobility on COVID-19 transmission has been demonstrated in the general population [8]. The reasons for homeless individuals to move may be multiple and are often related to personal situations [9]. However, very little is known about the geo-spatial behavior of homeless people [10], especially in crisis situations. Recognizing the territorialities of homeless people could be essential to improving access to care for this population. Therefore, the analysis of territorialities can contribute to the formulation of public policies aimed at ensuring health care for this vulnerable population group.

\section{Materials and Methods}

\subsection{Study Design}

We conducted a prospective population-based cohort study of homeless people living on the streets, in shelters or squats and slums: the COVID-Homeless survey (registered on ClinicalTrials, NCT04408131, May 29, 2020). This study aimed to exhaustively include participants from all shelters and outreach teams of the city. Each subject was tested twice: the first study lasted from June 5 to August 5, 2020 (first campaign), and the second three months later, September 11 to December 18, 2020 (second campaign). The homeless persons followed were tested for SARS-CoV-2 antibodies and answered a questionnaire concerning their life habits, socio-demographic data and recent geographic and residential movements.

\subsection{Study Area}

The study area was the city of Marseille. Marseille is the second largest city in France, but also the poorest. It is situated in the Southeast of France, in the Bouche du Rhône department, which was particularly affected by SARS-CoV-2. A large public health survey estimates the seroprevalence of SARS-CoV-2, based on 12,400 samples taken in May 2020, to be $4.5 \%$ for the whole of France and 5.2\% for the French region of Provence-Alpes-Côte d'Azur in which our study area is located [11]. On 17 March 2020, France entered its first lockdown, which ended on 11 May 2020. Following a resurgence of the epidemic after the summer of 2020, a second national confinement was been decreed from October 30 to December 15, 2020. Marseille, like all French cities, is divided into 3 administrative divisions, from the largest to the smallest: 16 districts, 111 neighborhoods and 742 units of equal size, called IRIS [12] . Most statistics and maps in this study are at the neighborhood scale, such as Figure 1, which depicts a map of districts and neighborhoods in Marseille, France. 


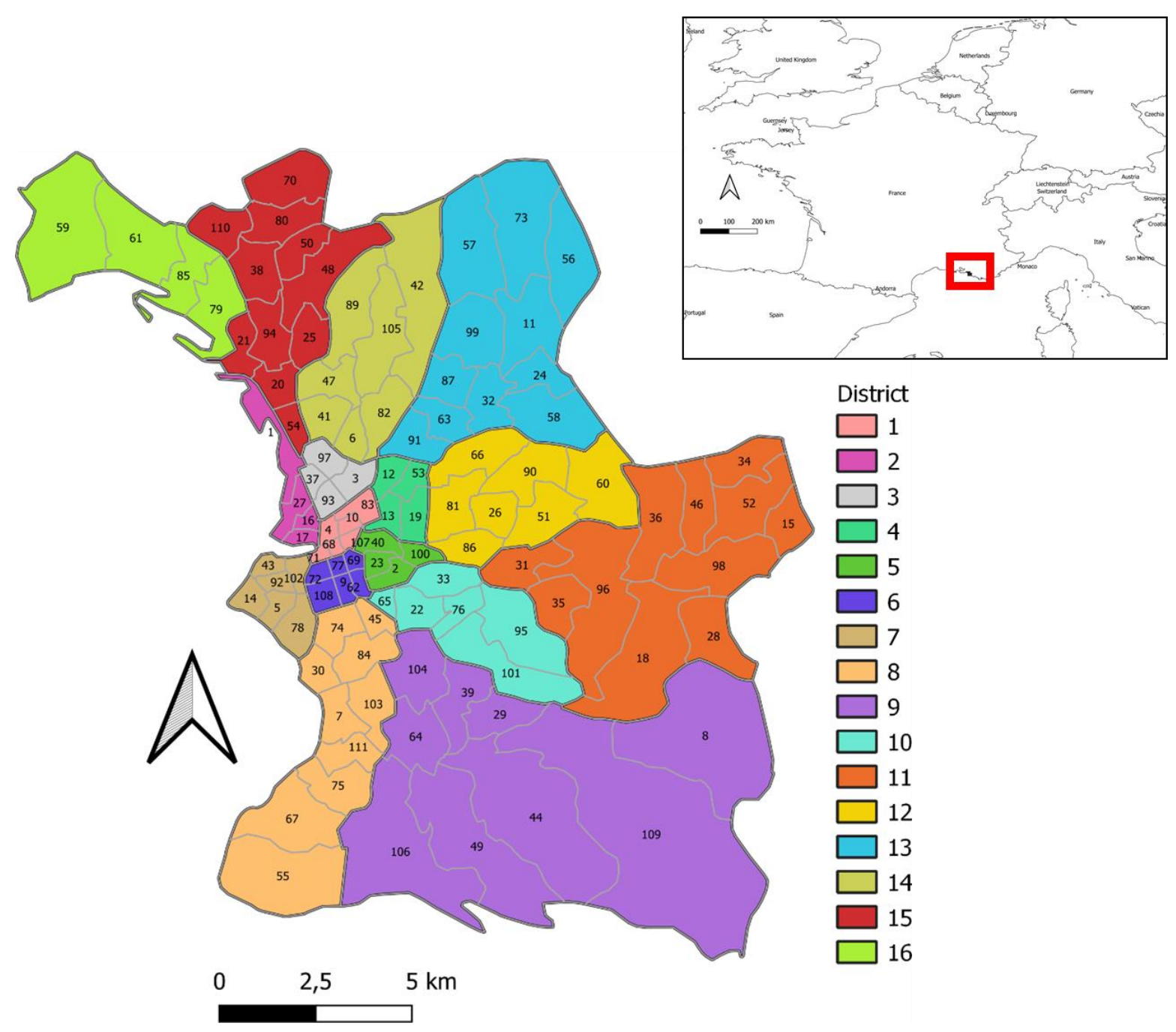

Figure 1. Map of districts and neighborhoods in Marseille, France. Neighborhoods are in alphabetical order according to their name (see Figure A1 and A2) and names of districts are numbered.

Marseille is the second most populous city in France, suffering a high level of poverty [13]. More than one out of two residents live below the poverty line (51.3\%) [14]. Marseille's impoverished neighborhoods contrast markedly with wealthy areas of the city, which benefit from good access to personal services, health institutions and shops, demonstrated by INSEE (French National Institute of Statistics and Economic Studies) classifications (Figure 2). To note, emergency accommodation in Marseille has a heterogeneous distribution. 


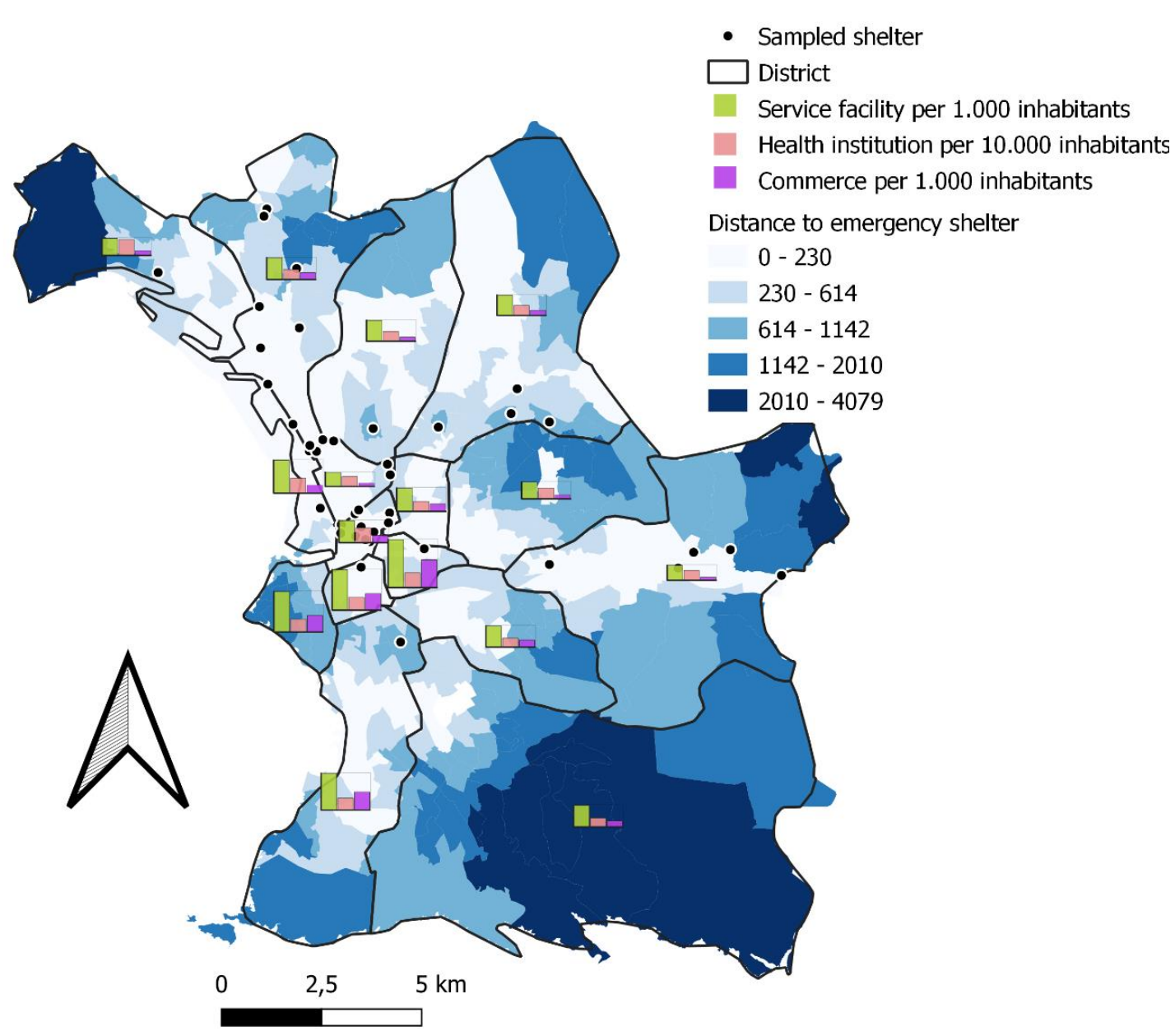

Figure 2. Map of the number of personal services (per 1,000 inhabitants), health institutions (per 10,000 inhabitants) and commerce (per 1,000 inhabitants) by district and distance to emergency shelter by IRIS, categorized into Jenks Natural Breaks Classification.

\subsection{Population}

To focus on homeless people with the greatest need, we decided to select homeless categories characterized by the greatest residential instability: people sleeping rough, in emergency shelters or hotels, in stabilization shelters, or in squats or slums, which correspond to the following categories of the European typology of homelessness: ETHOS 1, 2, 3 and 8 [15]. Data from the local orientation system (SIAO) for emergency and transitional accommodations and information from local NGOs estimated 2,800 homeless adult people living in such living conditions in Marseille in 2020, at the beginning of the COVID 19 outbreak. All the participants provided written informed consent. ETHOS categories were allocated according to the primary living location for the people questioned.

\subsection{Study design}

At each session, each participant was tested using a rapid diagnostic serological test (Byosinex), and completed a face-to-face interview investigating the following: socio-demographic characteristics; comorbidities; past and current medical history of COVID-19 (result and date of PCR testing, list of symptoms, cases in relatives or friends); difficulties in access to care, water, food or hygiene supplies; compliance with preventive measures (social distancing, wearing a mask, and hand washing). People with symptoms were invited to be tested by PRC test. Questions were asked by trained local interviewers in the 
participants' native language to improve comprehension and to minimize information bias [16].

\subsection{Biological Analysis}

We used the rapid serological test "Biosynex COVID-19 BSS®", providing the information about the presence of immunoglobulins $M(\operatorname{IgM})$ and $G(\operatorname{IgG})$ in 10 minutes. A Biosynex vitaPCR ${ }^{\circledR}$ was performed in case of symptoms of COVID-19 disease during the interviews [17], which provides results within 20 minutes.

\subsection{Outcomes and Data Analysis}

SARS-CoV-2 history of infection was defined by a positive SARS-CoV-2 serology (IgM or IgG) during the study period, or a positive PCR test. All of the statistical analyses were carried out using $\mathrm{R}$ software [18], and differences with $\mathrm{p}$ values of $<0.05$ were considered statistically significant.

Maps were made using QGIS software [19]. Data on the administrative boundaries of the city come from French government databases. For the multivariate analysis, we use stochastic regression imputation to asses variables for individuals with missing data, using the R package 'mice' [20]. For other analyses, complete case analyses were performed.

2.6.1 Socio-demographic factors and living areas

Multivariate statistics were performed with the R package ade4 [21, 22]. This analysis generalizes the PCA (Principal Components Analysis) method to be used with quantitative variables and factors [23]. The results and graphs read like those of a PCA [24]. This analysis was based on the responses of the participants in the first testing session.

2.6.2 Relation between mobility at the individual scale and infection with SARS-Cov-2

To find out if the number of accommodations in the past year was significantly associated with having a positive serological test for SARS-Cov-2, we used a multivariate logistic regression model. The explanatory variable is the 'Rest' variable and the response variable was the presence or absence of antibodies to SARS-CoV-2 at the individual level. To create the Rest variable, we used the following question: "How many nights has the person lived there?" linked with the question "What is the person's current housing?" and the question "For how many nights?" followed by the question "and before?". We averaged these variables to obtain an average number of nights stayed in each accommodation. This number was the continuous numeric variable 'Rest'.

\subsubsection{Life paths: mobility at the housing scale}

To illustrate mobility at the housing level, we used a Sankey diagram that shows mobility between ETHOS at 5 different time periods. The different periods were as follows: before the beginning of the health crisis (January 24, 2020), before the lockdown (between January 24 and March 16, 2020), during the lockdown (between March 16 and May 11, 2020), after the lockdown (between May 11, 2020 and August 5, 2020). All of this information was requested during the first campaign session. We also collected this information during the second test session (between September 11 and December 18, 2020) (second campaign). A Sankey Diagram was made using $\mathrm{R}$ software and the package networkD3 [25].

2.6.4 Mobility and Spatial epidemiology at the neighborhood scale

Satscan software [26] was used for cluster analysis to detect possible locations where the number of cases was higher than expected. We performed cluster analysis for the serological result for the first and second campaigns. We used purely spatial analysis, scanning for clusters with high rates. We used *the Bernoulli distribution and an elliptic 
window shape for scanning, with a maximum spatial cluster size of 50 percent of population at risk.2.7 Outcomes and Data Analysis.

\subsection{Ethical Approval}

The study was approved by the ethics committee Comité de Protection des Personnes d'Ile de France VI on May 28, 2020 (number 44-20). All of the people included in this study provided written informed consent. The database was anonymized and declared to the French regulatory commission (Commission Nationale Informatique et Libertés, CNIL, n²018172v0).

\section{Results}

We included 1272 people in the cohort (Table 1) 738 provided additional data during the second serological testing step (58.02\% of included people). In the first campaign, the majority of individuals were male $(70.29 \%, 894 / 1272)$, with an average age of 40.06 years (standard error: 0.40$)$ and $6.01 \%$ (74/1231) testing positive for SARS-CoV-2. In the second campaign, the majority of individuals were male $(71.7 \%, 545 / 738)$, with an average age of 41.76 years (standard error: 0.54$) .18 .86 \%$ (136/721) had SARS-CoV-2 antibodies.

Table 1. Sociodemographic characteristics of the study population who participated in first campaigns $(\mathrm{n}=1272)$.

\begin{tabular}{lcc}
\hline Sociodemographic characteristics & n (\%) or mean (SE) \\
\hline $\begin{array}{l}\text { Gender } \\
\text { Men }\end{array}$ & 894 & $(70.29 \%)$ \\
$\quad$ Women & 378 & $(29.71 \%)$ \\
Age (years) & 40.06 & $(0.40)$ \\
Household status & & \\
$\quad$ Isolated adult & 672 & $(52.83 \%)$ \\
$\quad$ Family & 416 & $(32.70 \%)$ \\
$\quad$ Isolated parent & 130 & $(10.22 \%)$ \\
$\quad$ Missing & 54 & $(4.25 \%)$ \\
Financial resources & & \\
$\quad$ No & 400 & $(31.45 \%)$ \\
$\quad$ Yes & 794 & $(62.42 \%)$ \\
$\quad$ Missing & 78 & $(6.13 \%)$ \\
Problems of economic resources during the & & \\
period of health crisis & & $(25.24 \%)$ \\
$\quad$ No & 321 & $(69.42 \%)$ \\
Yes & 883 & $(5.35 \%)$ \\
Missing & 68 & $(18.55 \%)$ \\
Country of Birth & & \\
France & 236 &
\end{tabular}

\footnotetext{
1 “European Union” countries: Belgium, Bulgaria, Germany, Hungary, Italy, Poland, Portugal, Romania, Czech Republic, Slovakia, and Spain. “Outside European Union” countries: Albania, Armenia, Bosnia, Croatia, Moldavia, Montenegro, Serbia, Russia including Chechnya, and Ukraine.
} 


$\begin{array}{lcc}\text { European Union } & 199 & (15.64 \%) \\ \text { Europe, non-European Union } & 212 & (16.67 \%) \\ \text { North Africa } & 282 & (22.17 \%) \\ \text { Sub-Saharan/Southern Africa } & 213 & (16.75 \%) \\ \text { Middle East } & 15 & (1.18 \%) \\ \text { Russia } & 31 & (2.44 \%) \\ \text { North America } & 2 & (0.16 \%) \\ \text { South America } & 17 & (1.34 \%) \\ \text { Missing } & 65 & (5.11 \%)\end{array}$

Education attainment

$\begin{array}{lcc}\text { No educational achievement } & 607 & (47.72 \%) \\ \text { Lower secondary } & 329 & (25.86 \%) \\ \text { Upper secondary or vocational } & 246 & (19.34 \%) \\ \text { Missing } & 90 & (7.08 \%)\end{array}$

Health insurance

\begin{tabular}{ccc} 
No & 247 & $(19.42 \%)$ \\
Yes & 952 & $(79.84 \%)$ \\
Missing & 73 & $(5.74 \%)$ \\
\hline Living conditions & n (\%) or mean (SE) \\
\hline
\end{tabular}

Total length of homelessness

$<3$ months

90

3 to 12 months

240

1 to 5 years

452

$>5$ years

397

Missing

93

$(7.31 \%)$

ETHOS² Typology at baseline

ETHOS 1: street

166

ETHOS 2: emergency shelters and

447

$(35.14 \%)$

hotel rooms

172

ETHOS 8: squats, slums

485

$(38.13 \%)$

Missing

2

$(0.16 \%)$

\section{Health characteristics}

n (\%) or mean (SE)

Tobacco consumption

$\begin{array}{lcc}\text { No } & 486 & (38.21 \%) \\ \text { Yes } & 655 & (51.49 \%) \\ \text { Missing } & 131 & (10.3 \%) \\ \text { ol consumption (glasses per day) } & 0.48 & (0.03) \\ \text { Nonce consumption } & & \\ \text { No } & 903 & (70.99 \%)\end{array}$

${ }^{2}$ ETHOS: the European typology for homelessness and housing exclusion. 
Yes 218

Missing

Number of Comorbidities

Serological test for SARS-CoV-2

$\begin{array}{lc}\text { Negative } & 1157 \\ \text { Positive } & 74 \\ \text { Missing } & 41\end{array}$

\subsection{Socio-demographic factors and living areas}

In the multivariate analysis, axis 1 contrasted two types of people. The first group comprised people born in France, who take drugs, whose education was lower secondary, who were isolated parents and live in ETHOS 1 . The opposing group characteristics were female, born in European countries including non-members of the European Union (EU), who lived in families and lived in ETHOS 8 housing (Figure 3, Table A1). Axis 2 opposed two types of people. The first group concerned people born in countries of sub-Saharan or Southern African countries, MiddleEastern countries, North and South American countries, who did not smoke. They were contrasted with people born in European Union countries and in France, who took drugs, who have been homeless for more than 5 years and lived in ETHOS 1 housing (Figure 3, Table A1). The housing situation was an important variable in this analysis (Table A1).

On the first axis of the analysis, ETHOS 1, 2 and 3 are opposed to ETHOS 8. On the second axis, ETHOS 1 and 8 are opposed to ETHOS 3 and 2.

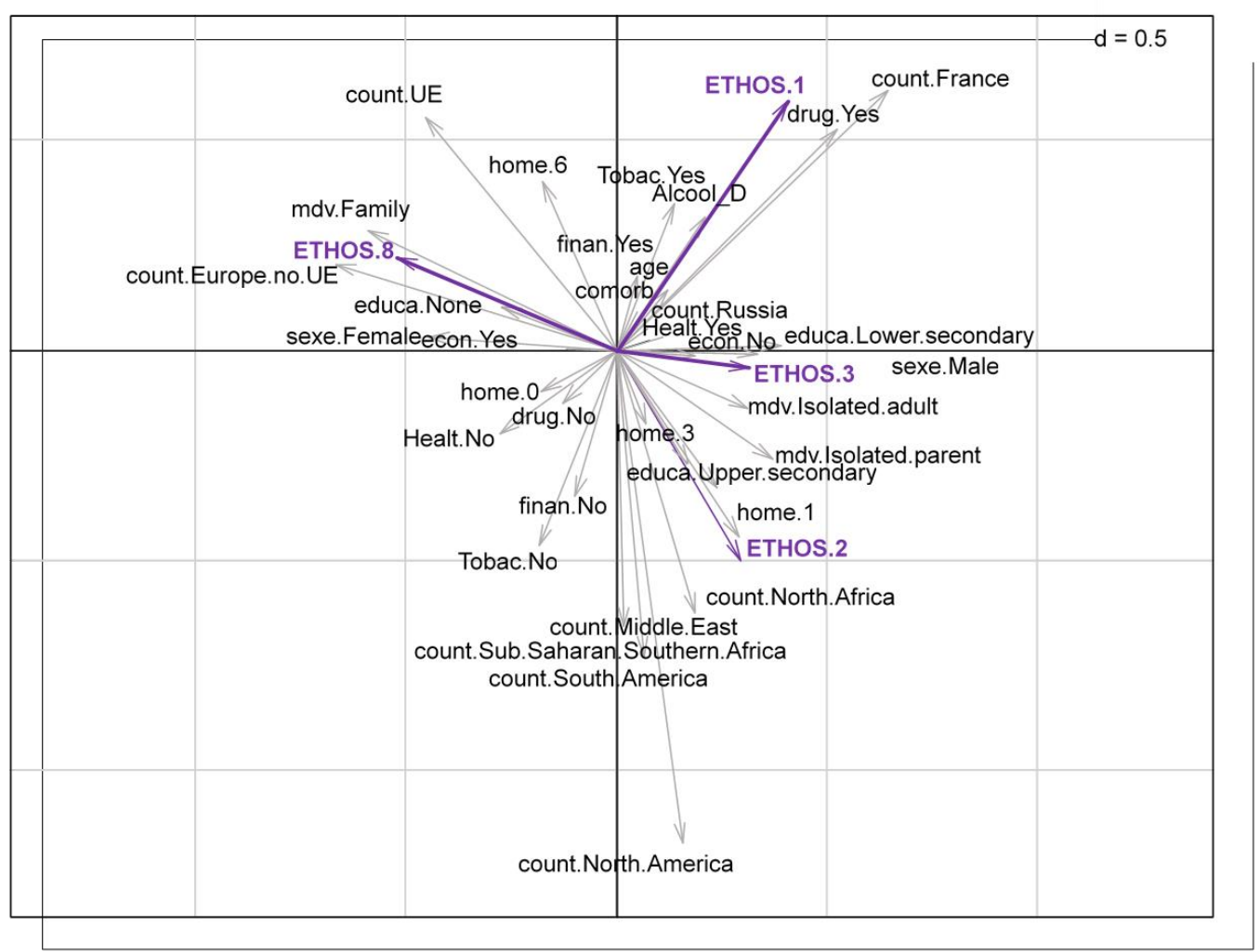

Figure 3. Scatter diagram of the projection of the variables in the first two axes of multivariate analysis with mixed quantitative variables and factors.

\subsection{Relation between mobility at the individual scale and infection with SARS-Cov-2}

The number of different accommodations in the past year is significantly associated with having a positive serological test for SARS-Cov-2 (Table 2). 
Table 2. Univariate analysis of the seroprevalence of SARS-CoV-2 infection between June and August 2020 in homeless people living in Marseille.

\begin{tabular}{lcc}
\hline & HR (IC95\%) & p-value \\
\hline $\begin{array}{l}\text { Number of different accom- } \\
\text { modations in the past year }\end{array}$ & $1.2(1.007-1.424)$ & 0.049 \\
\hline
\end{tabular}

\subsection{Life paths: mobility at the housing scale}

Before the beginning of the health crisis (January 2020), 13.08\% of the people were counted in ETHOS 1 (166/1270), 35.2\% in ETHOS 2 (447/1270), 38.19\% (485/1270) in ETHOS 8 and 13.54\% in ETHOS 3 (172/1270) (Figure 4). Between January, 2020 and March, 2020 , beginning of the first lockdown, 13.63\% (165/1211) of the population changed their accommodation status. During the first lockdown (March to May, 2020), 15.27\% (178/1166) of people moved. The most important flows were those of people going to ETHOS 2 (emergency shelters). Thus $30.56 \%$ (44/144) of people in ETHOS 1 before the first lockdown went to ETHOS 2 during the first lockdown, 9.84\% (44/447) of people in ETHOS 8 went to Ethos 2 and $27.27 \%$ (12/44) of people in the 'other' category also went to ETHOS 2. Although a number of people left ETHOS 2 to go primarily to ETHOS $3(4 \%, 14 / 352)$ between these dates, the flows were positive for ETHOS 2, which saw its population increase from $29.10 \%$ (353/1213) of reported housing types to $36 \%(440 / 1223)$ during the lockdown. After the first lockdown (end in May 11, 2020), 13.85\% (168/1213) of people moved. ETHOS 2 continued to receive people. Thus 31\% (31/100) of people in ETHOS 1 during the lockdown went to ETHOS 2 after the lockdown. 9.18\% (37/403) of people in ETHOS 8 went to ETHOS 2 after the lockdown and 27\% (10/36) of people in the other category went to ETHOS 2 as well. Between the two testing sessions (May to December, $2020), 23.17 \%$ (165/712) of people moved. The most important flow was between people in ETHOS 2 after the lockdown and those in ETHOS 3 during the second testing session: $24.4 \%$ (71/291). This flow corresponded to people in emergency shelters who went to homeless hostels (transitional hostels, temporary accommodation, or transitional accommodation with support). 


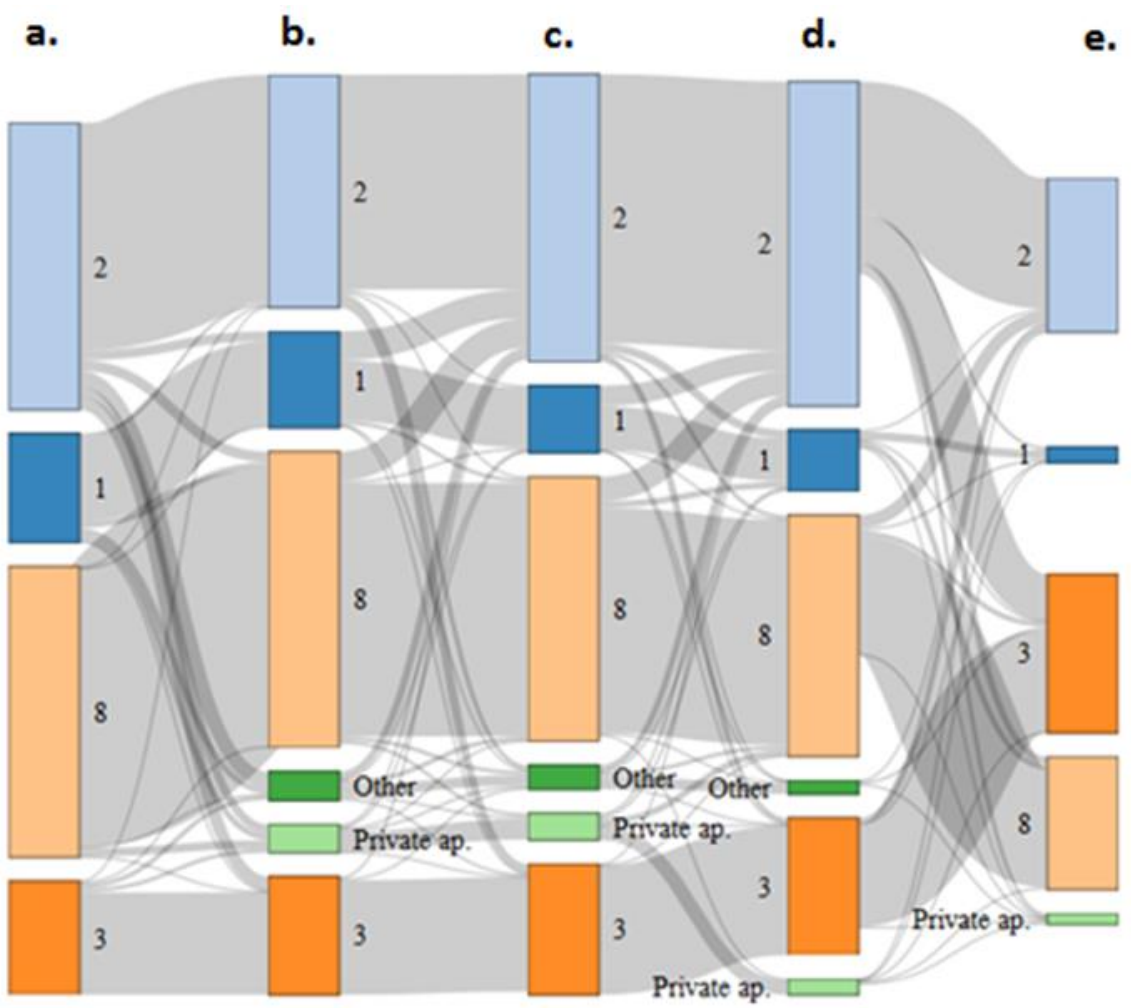

Figure 4. Sankey diagram of life paths in our study. Different periods are: a. before the beginning of the health crisis (January 24, 2020), b. before the lockdown (between January 24 and March 16, 2020), c. during the lockdown (between March 16 and May 11, 2020), d. after the lockdown (between May 11, 2020, and August 5, 2020) and e. during the second testing session (between September 11 and December 18, 2020).

1 indicate ETHOS 1, 2 indicate ETHOS 2, 3 indicate ETHOS 3, 8 indicate ETHOS 8, Private ap. indicate persons in private apartment and Other indicate other types of housing.

\subsection{Mobility and Spatial epidemiology at the neighborhood scale}

For the population dynamics of mobility between the first and second campaigns, we have information about 377 people in the first campaign and 721 in the second campaign. We have information about the population dynamics in 45 of the 110 neighborhoods in Marseille. Of these 45 neighborhoods, 21 (46.7\%) lost people between the first campaign and the second campaign, $19(42.22 \%)$ gained people, and $5(11.11 \%)$ had an equivalent number of respondents (Figure 5). 


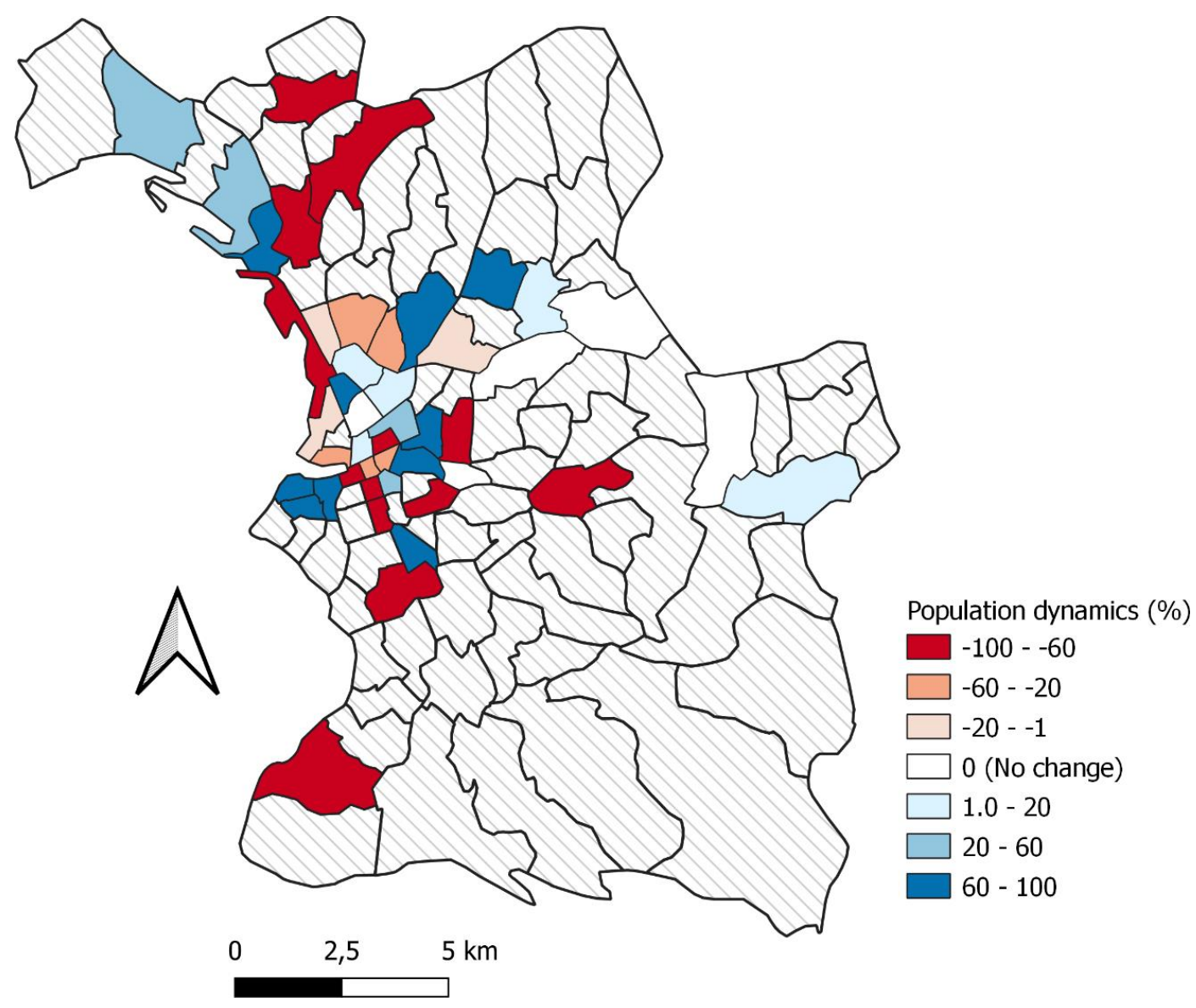

Figure 5. Population mobility between the first and second campaigns at the neighborhood scale. Neighborhoods in red indicate that they lose people between the first campaign and second campaign, neighborhoods in blue win people. Neighborhoods with no data are in hashed gray.

For the first period of testing (from June 5 to August 5, 2020), we had the test results of 377 people with associated geographical coordinates. We tested 39 neighborhoods out of the 110 in the city of. The prevalence per neighborhood was between 0 and 0.5 (Figure 6 , Table A1). The total prevalence, across all neighborhoods combined (for the 377 people) was $2.65 \%$ (IC95\%: 1.03-4.27\%). 

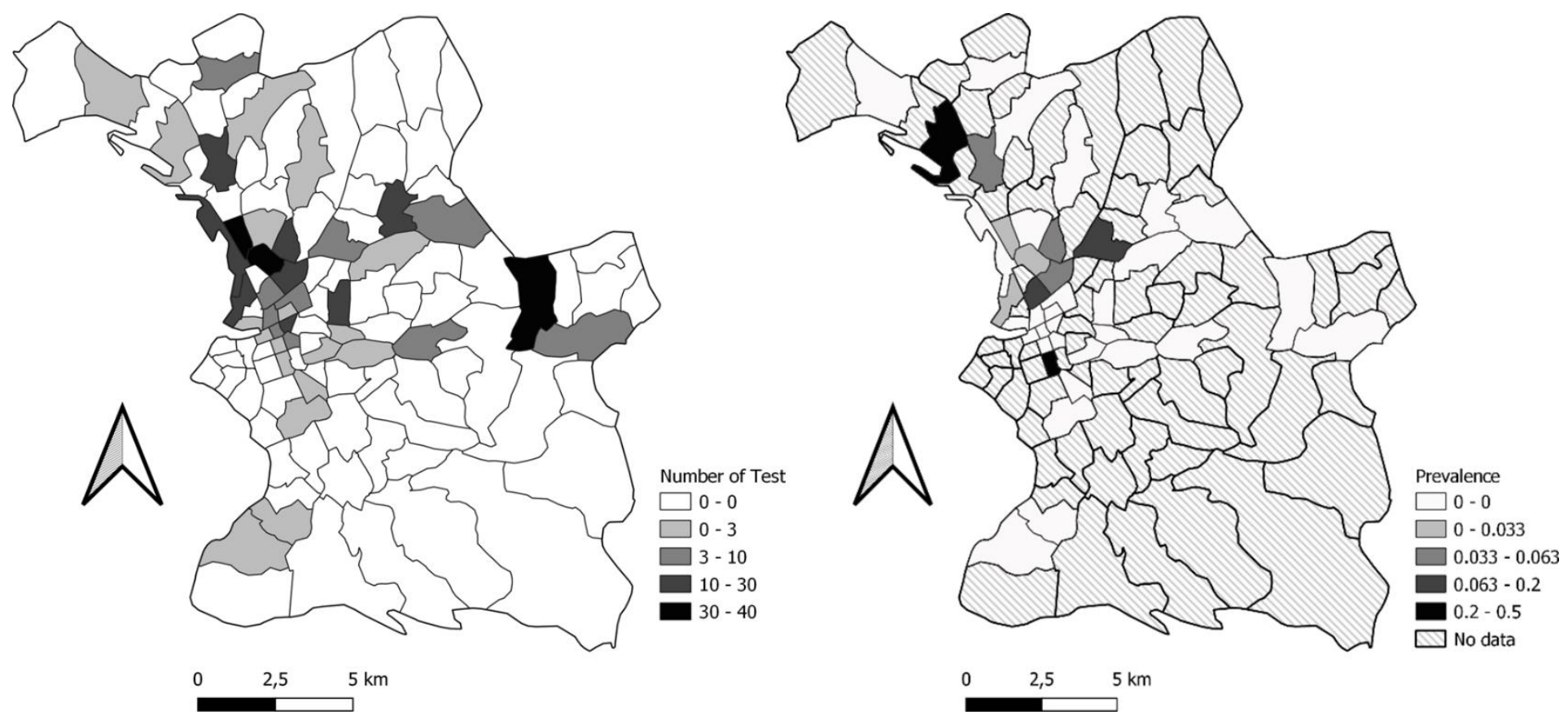

Figure 6. (a) Map of the number of tests performed by neighborhood for the first testing period (first campaign) in Marseille City, categorized into Jenks Natural Breaks Classification.; (b) Map of prevalence by neighborhood for the first testing period (first campaign) in Marseille City, categorized into Jenks Natural Breaks Classification.

For the first campaign, we identified a nonsignificant cluster in the neighborhoods north-west of Marseille (Population $=168$, Number of cases $=8$, expected cases: 4.46, Observed/expected: 1.80, Relative risk: 4.98, log likelihood ratio: 2.711407, P-value: 0.75, not a Gini Cluster) (Figure 7, Table A1). 


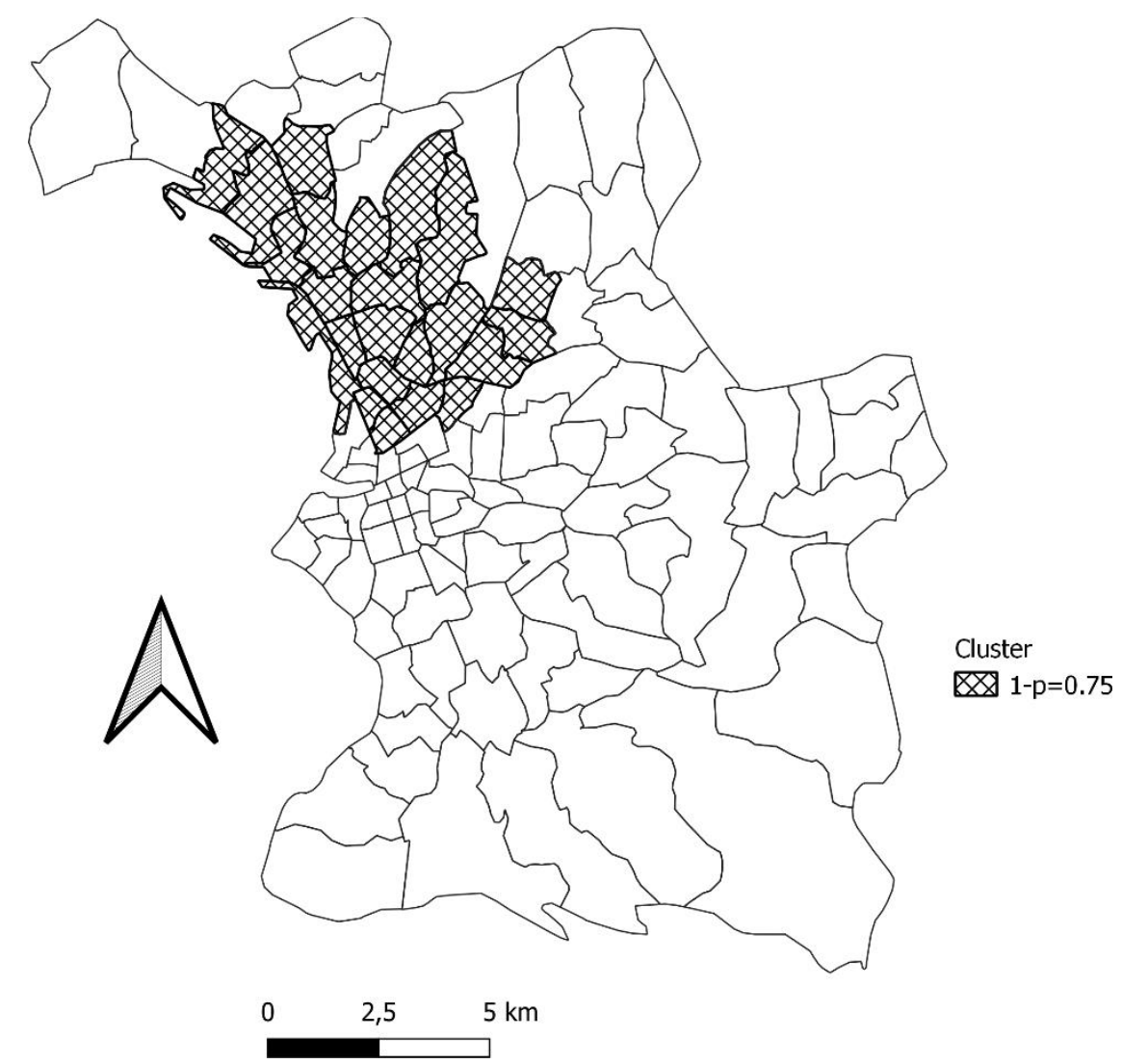

Figure 7. Map of clusters identified for the first testing period (first campaign) in Marseille City.

For the second period of testing (from September 11 to December 18, 2020), we had the tests of 721 people with associated geographical coordinates. We tested 43 neighborhoods out of the 110 in the city of Marseille. The prevalence per neighborhood was between 1 and 0.024 (Table A2, Figure 8). The total prevalence, across all neighborhoods combined (for the 721 people) was 10.12\% (IC95\%: 7.923-12.23).
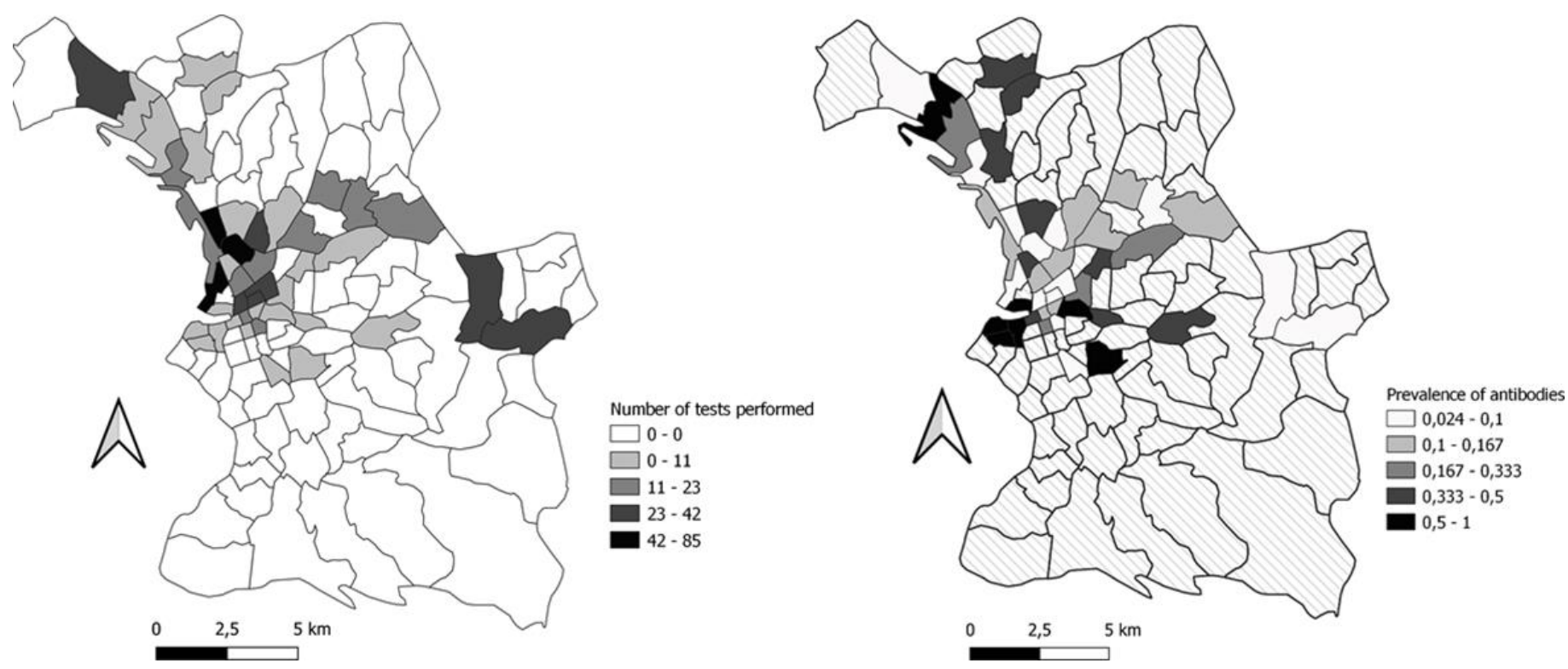

Figure 8. (a) Map of the number of tests performed by neighborhood for the second testing campaign period in Marseille City, categorized into Jenks Natural Breaks Classification.; (b) Map of prevalence by neighborhood for the second testing period in Marseille City, categorized into Jenks Natural Breaks Classification. 
For the period of the second campaign, 4 clusters were identified, two of which are significant and two not significant (Table 2, Figure 9, Table A2): a significant cluster of 6 neighborhoods (cluster 1), around the old port of Marseille; a significant cluster of 16 neighborhoods (cluster 2), located in the center of Marseille; a nonsignificant cluster of 8 neighborhoods (cluster 3) in the north of Marseille; and a non-significant cluster which was located in the neighborhood of La Villette (cluster 4).

Table 3. Result of the cluster analysis for the second period testing period, the neighborhoods concerned for each cluster are indicated in Table A1.

\begin{tabular}{ccccccccc}
\hline Cluster & Population & $\begin{array}{c}\text { Number of } \\
\text { cases }\end{array}$ & $\begin{array}{c}\text { Expected } \\
\text { cases }\end{array}$ & $\begin{array}{c}\text { Observed / } \\
\text { expected }\end{array}$ & Relative risk $\begin{array}{c}\text { Log } \\
\text { likelihood } \\
\text { ratio }\end{array}$ & P-value & Gini cluster \\
\hline 1 & 5 & 5 & 0.51 & 9.88 & 10.53 & 11.608803 & 0.00082 & yes \\
2 & 18 & 8 & 1.82 & 4.39 & 4.81 & 7.329902 & 0.029 & yes \\
3 & 20 & 8 & 2.02 & 3.95 & 4.31 & 6.429304 & 0.070 & no \\
4 & 5 & 2 & 0.51 & 3.95 & 4.03 & 1.552775 & 0.991 & no \\
\hline
\end{tabular}

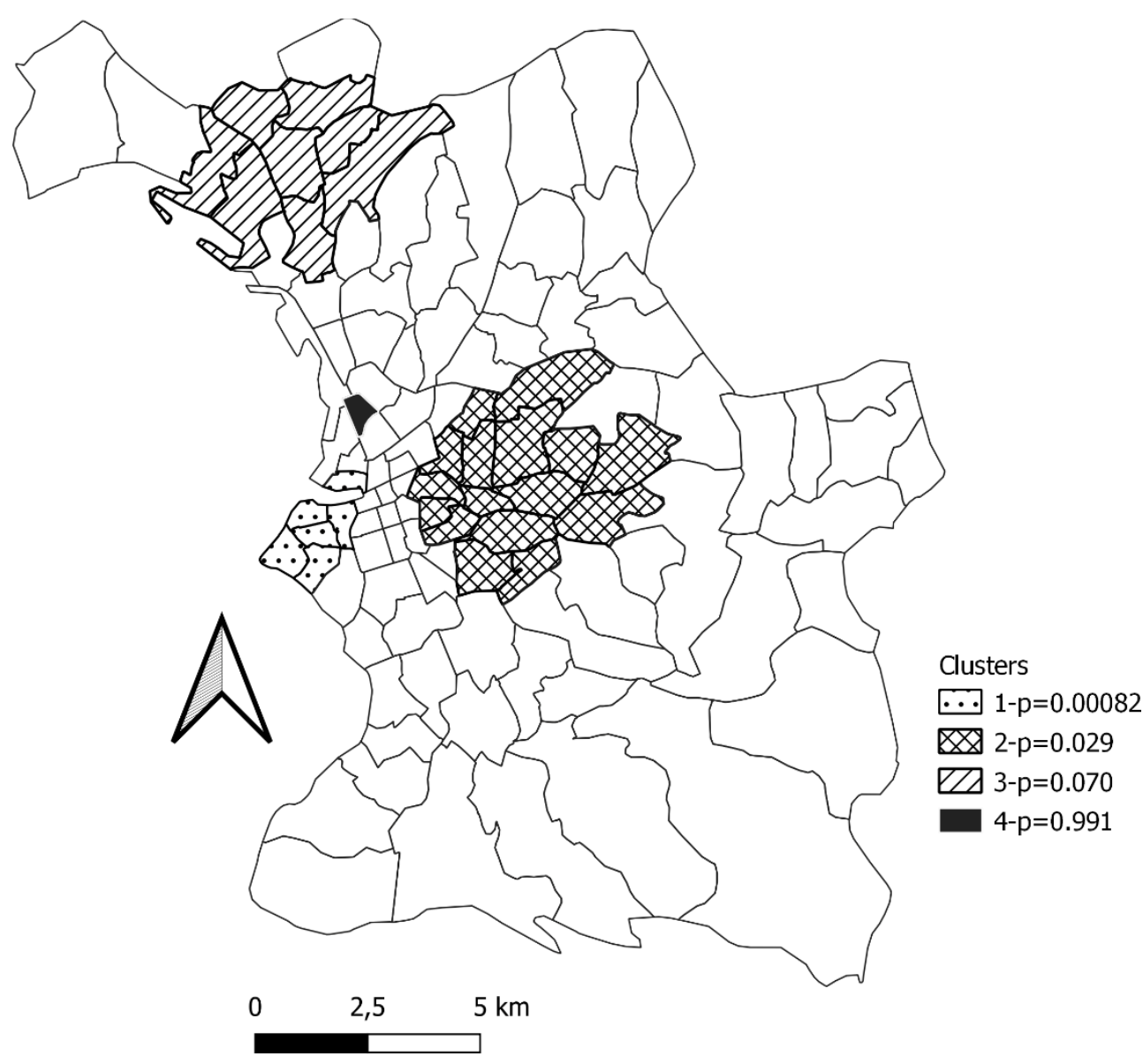

Figure 9. Map of clusters identified in the second period testing period in Marseille City. 


\section{Discussion}

In this paper we have shown that the most mobile individuals, with a greater number of different dwellings in the past year, were at greater risk of testing positive for SARSCoV-2. This association has already been demonstrated in other studies $[8,27]$ and showed the importance of residential stability in order to comply with isolation and social distancing measures. This study was made possible by the close involvement of local NGOs in the field. We also shown that the homeless population in a large European city such as Marseille is very heterogeneous, both in terms of personal circumstances and type of homelessness (on the street, in emergency accommodation...). Compared to the general population of Marseille, the homeless population is younger and consists of more men. Different types of homelessness had a clear relationship to personal characteristics. Country of birth was a significant variable in the analysis affecting the type of homelessness people experienced. It is possible to distinguish several groups: One group was made up of people born in France, who consumed alcohol, tobacco and used other drugs users whilst living on the streets. Another group comprised people living with their families, in squats and shantytowns, born in Europe (outside and inside the European Union), who tended to remain in one area. The last group, less differentiated, was made up of people living in emergency shelters and transit shelters, parents or single adults with a secondary level of education, born in Africa, the Middle East or America (North and South). Whilst our study highlighted the heterogeneity of the homeless population within Marseille we were able to draw attention to the existence of new categories of people and the need for help adapted to their specific needs. Our study population was mobile in different ways during the year 2020, corresponding to the beginning of the Covid-19 crisis in France. Mobility varied according to the type of homelessness experienced at the beginning of the crisis. Our study showed that the flow of people between different types of accommodation increased from the lockdown onwards, compared to periods in between where restrictions were eased. This was mainly because the flow of people living in squats and on the streets into emergency accommodation increased after the lockdown. Populations who were on the streets before the crisis were most likely to move to emergency accommodation. These observations reflect an effort by NGOs and politicians to encourage people into shelters during the first lockdown in France. This movement of people continued until the period from May to August 2020. During the second test session, the most notable population flows occurred from emergency shelters towards ETHOS 3 housing. This corresponds to a cessation of Covid-related emergency accommodation and to people moving to more stable shelters. According to the step-by-step model, this shift allowing for support of the people concerned and aimed at their insertion into housing. This was a standard institutional process, which accelerated after the Covid crisis following political commitments promising that people would not end up back on the streets. These observations raised another problem from an epidemiological point of view: another study concerning the same cohort, Mosnier, 2021 [28] showed that people in emergency shelters were more likely to test positive for SARS-CoV-2 than those who remained on the streets or in slums. These observations were similar to those [6] in the USA. Our observations question contemporary homelessness social policies. Our Sankey diagram showed that emergency accommodation is not limited to people staying under 'emergency' conditions. In an ideal world, the 'step-by-step' model aims to facilitate the progressive movement of homeless people from the streets to emergency shelters (ETHOS 2), and then onwards to stabilization shelters (ETHOS 3 ) in order to help prepare them for private housing. This model remains dominant at the policy level, despite the existence of other models like Housing First, which promote direct and unconditional access to housing and have proven more effective at producing housing stability [29, 30]. Our study shows (Figure 4) that there were very few instances of people moving from homeless directly to private housing, and lots of people in the step-by-step model, experiencing long stays in emergency shelters and little access to stabilization shelters at a later stage. Furthermore, shelters seemed ill adapted to families without education, which were staying in slums (Figure 
3 and 4). Although it seems that shelters appeared as the easiest solution to provide rapid protection for homeless people, there was no long-term solution after the initial emergency response. As discussed, these emergency solutions also involved greater risks of infection [3, 28]. For the authors, the step-by-step model and emergency policies for homelessness need to be radically transformed. Our study also highlighted the mobility of the homeless population. People could be mobile within a neighborhood, a city, a country or a continent (intra-European mobility, for example). We looked at mobility at the level of a city's neighborhoods, the possible reasons for such mobility and its consequences in epidemiological terms. In this part of the study, we observed an effective mobility between the first and second campaigns, with some neighborhoods gaining population, whilst others decreased. The homeless population was also mobile within neighborhoods, which may have an impact on outbreaks. In terms of epidemiology, during the first campaign period, we detected a non-significant cluster in the northern neighborhoods of Marseille, which are notably poorer than the rest of the city [14]. During the second campaign period, we detected four clusters. The cluster detected in the first campaign in the northern districts was still present but included fewer districts than those identified in the first campaign. We also identified a cluster in the vicinity of the old port of Marseille, a cluster in the center of the city and one further in the district of La Villette. According to Kaufman, 2020 [9], research concerning the mobility of homeless people emphasizes moves within cities and reveals seven factors worthy of note: housing; labor markets; social, health, and justice services; personal health; the attributes of different places; interpersonal networks; and how mobility is socially differentiated. He identified four other motivations, particularly for mobility across Canada: social connections, the influence of different places, and personal finances, all of which could drive people to move between different locations. Homeless people from all kinds of accommodation were found to have an notable daily mobility [31], but little is known about their residential mobility over several months. Allaria et al. (2021) [32] report that the lockdown of the general population in France severely impacted the survival systems of the populations furthest from housing, with alarming rates of people without access to water or food. In addition, $77 \%$ of homeless participants reported that they encountered significant financial difficulties. Under the effects of a pandemic, there are additional constraints specific to the health crisis, which compound those constraints specific to homelessness: emergency accommodation link, continuation of a disrupted economic activity, etc. In summary, the mobility of homeless people at the city-scale is an important factor in better understanding the epidemiological dynamics for these populations. To date, these questions have been under investigated, despite concerning the public health of the most precarious people. herein this study, we highlight the need for further research on these important issues. These results encourage the implementation of management adapted to the specific situations of these particularly vulnerable populations in times of health crisis.

\subsection{Limitations}

A selection bias cannot be ruled out since we had no reliable census data from which to perform random sampling. However, we aimed at exhaustiveness by systematically including all homeless adults encountered in the field during the inclusion period with our partners, which included all shelters and homeless mobile outreach teams in the city. This extensive recruitment and the overall size of our study population limits this bias. Homeless people living in the streets (ETHOS 1) were harder to reach and more are lost to follow-up, despite the commitment involvement of all study partners, including NGOs. Although some government measures increased the mobility of the homeless population from living on the streets to emergency accommodation, other measures had the potential to reduce population mobility. For example, the 'winter eviction ban', which forbids the eviction of a tenant during the winter months, was extended by decree (Ordinance $\mathrm{n}^{\circ} 2020$ 331 of March 25, 2000 (JORF March 26, 2000)[33]). Entry restrictions on homeless accommodation and restrictions on the length of stay in shelters was also suspended for the 
duration of the lockdown. The high levels of mobility observed in our study are perhaps surprising given this context, and might lead one to expect higher mobility in this population today with the cessation of these measures. There was a bias concerning the map in figure 5, as we had more spatial location information for people in the second campaign than in the first: the population dynamics of the neighborhoods therefore risks exaggeration towards the positive. Nevertheless, this map is still relevant for comparing neighborhoods with each other. The lower number of spatialized data in the first campaign could also explain why the cluster identified there does not emerge as statically significant.

\section{Conclusions}

Our study provides a useful first description of the mobility of homeless people in a period of epidemiological crisis, identifying different types of mobility and associated epidemiological consequences. Although we focused on the city of Marseille, similar mechanisms are likely to be notable for other cities in developed countries. Our study can thus be used by public authorities to better understand and manage the mobility of homeless people in times of health crisis.

Author Contributions: Wrote the first draft of the manuscript: AA. Contributed to the writing of the manuscript: EM, AT, SL, CF, JL and MM. collected the data and samples. EM, CF, MM. Analyzed the data: AA, JL and JD. Conceived the study: EM, SL, PA, AT and CF. All authors contributed to subsequent draft have reviewed and agreed with the content of the final manuscript.

Funding: This study was supported by the DGOS (PHRC-COVID-19 : 20-0047, study ID 2020-

AO1398-31).

Institutional Review Board Statement: This study was approved by ethical committee on May 28, 2020 (number 44-20).

Informed Consent Statement: Informed consent was obtained from all subjects involved in the study.

Data Availability Statement: The datasets generated and analyzed during the current study are not publicly available due to special authorization to transfer databases given by the CNIL. Upon prior authorization by the CNIL, the dataset would be available from corresponding author on a reasonable request. Additionally, the study protocol is available for the request. All data requests should be directed to the corresponding author.

Acknowledgments: We would like to thank all the homeless people who participate in this study by providing their samples and questionnaires. We would also like to thank all the following: the nurse interweaves and mediators involved in the 'COVID homeless' project: Maud Landreau, Anne Ranise and Nathalie Vuagniaux, Grâce Inegbeze, Snjezana Huette, Marko Sava, and Drisse Mekkaoui ; the Assab network; the following Homeless outreach teams: ADDAP13, AMPIL, ASUD, Bus 31/32, Equipe Mobile d'Aide (EMA) Saralogisol, Equipe Mobile santé ADJ Marceau, Equipe Mobile Gare et Connexion ADJ Marceau, MARSS-APHM, Nouvelle Aube, Mission Bidonville Médecins du monde, PASS adulte APHM, Réseau Santé Marseille Sud (RSMS); the following Emergency shelters: UHU La Madrague-ville, St Louis, Sleep'in (groupe SOS Solidarité), Forbin (Fondation St Jean de Dieu), Marius Macias (AAJT) and the following persons involved in providing Collective accommodation for homeless persons: Marius Macias (AAJT); William Booth (Armée du Salut); Le Marabout, le Mascaret (Habitat Alternatif Social); Foyer Honorat (Hospitalité pour les Femmes); Jane Pannier (Maison de la Jeune Fille); SHAS (Saralogisol) Coco Velten, La Selonne (groupe SOS Solidarité); Forbin (St Jean de Dieu); Village Club du Soleil; for their work in improving the care management of homeless people in Marseille.

Conflicts of Interest: The authors declare no conflict of interest 


\section{Appendix A}

Table A1. Coordinates of each variable on axis 1 (CS 1) and 2 (CS 2) of the multivariate analysis. In gray the 5 most important variables on axes 1 and 2 of the multivariate analysis.

\begin{tabular}{|c|c|c|c|}
\hline Variable & CS1 & CS2 & \\
\hline mdv.Isolated.adult & 0.318020814614317 & -0.138686155266092 & Household status: Isolated adult \\
\hline mdv.Family & -0.596581877218025 & 0.268218556893136 & Household status: Family \\
\hline mdv.Isolated.parent & 0.371420323213889 & -0.189431086881132 & Household status: Isolated parent \\
\hline econ.No & 0.329645002280672 & -0.03784583794277 & $\begin{array}{l}\text { Problems of economic resources during the pe- } \\
\text { riod of health crisis : No }\end{array}$ \\
\hline econ.Yes & -0.118334103382805 & 0.0135856854153533 & $\begin{array}{l}\text { Problems of economic resources during the pe- } \\
\text { riod of health crisis : Yes }\end{array}$ \\
\hline comorb & 0.0601445363544964 & 0.143583595180596 & Number of Comorbidity \\
\hline age & 0.141722722286938 & 0.199677009063853 & Age in year \\
\hline count.France & 0.657142200949126 & 0.565684402668609 & Person's country of birth: France \\
\hline count.UE & -0.461402761339287 & 0.565496784946139 & $\begin{array}{l}\text { Person's country of birth: country of European } \\
\text { Union }\end{array}$ \\
\hline count.Europe.no.UE & 0.227542076216351 & 0.227542076216351 & $\begin{array}{l}\text { Person's country of birth: country of Europe, not } \\
\text { in European Union }\end{array}$ \\
\hline count.North.Africa & 0.30389661463267 & -0.445676499984632 & $\begin{array}{c}\text { Person's country of birth: country of North Af- } \\
\text { rica } \\
\end{array}$ \\
\hline $\begin{array}{l}\text { count.Sub.Saharan } \\
\text {.Southern.Africa }\end{array}$ & -0.00692548059787189 & -0.693042068909341 & $\begin{array}{l}\text { Person's country of birth: country of Sub-Sa- } \\
\text { haran or Southern African countries }\end{array}$ \\
\hline count.Middle.East & 0.182154429482761 & -0.579650734253128 & Person's country of birth: country of Middle East \\
\hline count.Russia & 0.000515391122827311 & 0.063809437909346 & Person's country of birth: Russia \\
\hline count.North.America & 0.194660784564911 & -0.989836831994614 & $\begin{array}{c}\text { Person's country of birth: country of North } \\
\text { America }\end{array}$ \\
\hline count.South.America & 0.0640708015214596 & -0.710434782575241 & $\begin{array}{l}\text { Person's country of birth: country of South } \\
\text { America }\end{array}$ \\
\hline sexe.Male & 0.193604145684412 & -0.0016711647920521 & Sexe: Male \\
\hline sexe.Female & -0.457889169952026 & 0.00395243736533019 & Sexe: Female \\
\hline finan.Yes & 0.050688018372308 & 0.172342681477751 & Financial resources: Yes \\
\hline finan.No & -0.101735526236618 & -0.34590765147662 & Financial resources: No \\
\hline educa.None & -0.273718530606828 & 0.103928647366441 & Education attainment: None \\
\hline $\begin{array}{l}\text { educa.Lower.secon- } \\
\text { dary }\end{array}$ & 0.415103314713079 & 0.0182723622263325 & Education attainment: Lower secondary \\
\hline $\begin{array}{l}\text { educa.Upper.secon- } \\
\text { dary }\end{array}$ & 0.138676787874378 & -0.285382577809815 & Education attainment: Uper secondary \\
\hline Healt.Yes & 0.0730428304542106 & 0.0286390463874196 & Health insurance : Yes \\
\hline Healt.No & -0.27363806632846 & -0.107289561839437 & Health insurance : No \\
\hline
\end{tabular}




\begin{tabular}{|c|c|c|c|}
\hline Tobac.No & -0.175282864892875 & -0.464552790157363 & Tobacco consumption: No \\
\hline Tobac.Yes & 0.128891492738417 & 0.341601574208484 & Tobacco consumption: Yes \\
\hline Alcool_D & 0.2129663952661 & 0.310894858612279 & $\begin{array}{l}\text { Alcohol consumption in number of standard } \\
\text { glasses per day }\end{array}$ \\
\hline drug.No & -0.120115203696184 & -0.119479595798671 & Drug consumption: No \\
\hline drug.Yes & 0.491030952710004 & 0.488432587624964 & Drug consumption: Yes \\
\hline home.0 & -0.204960195548446 & -0.210235966368546 & $\begin{array}{c}\text { Total length of homelessness: Less than } 3 \\
\text { months }\end{array}$ \\
\hline home.1 & 0.226974290324227 & -0.351706113500525 & Total length of homelessness: Less than 1 year \\
\hline home.3 & 0.0607296491464919 & -0.191823511717764 & Total length of homelessness: 1 to 5 years \\
\hline home.6 & -0.158247979029243 & 0.4797275092935 & Total length of homelessness: More than 5 years \\
\hline ETHOS.1 & 0.377426671611134 & 0.538257285433284 & Housing situation: ETHOS 1 \\
\hline ETHOS.2 & 0.294737185619723 & -0.414156583347008 & Housing situation: ETHOS 2 \\
\hline ETHOS.8 & -0.527713370478378 & 0.20237575177422 & Housing situation: ETHOS 8 \\
\hline ETHOS.3 & 0.354022532005372 & -0.0113341020402295 & Housing situation: ETHOS 3 \\
\hline
\end{tabular}

Appendix B

Table B1. Number of tests performed, number of positive tests, prevalence and cluster number for the first campaign

\begin{tabular}{|c|c|c|c|c|c|c|}
\hline Neighborhood & $\begin{array}{c}\text { Neighborhood } \\
\text { Number }\end{array}$ & District & $\begin{array}{c}\text { Number of } \\
\text { tests }\end{array}$ & $\begin{array}{c}\text { Number of } \\
\text { positive tests }\end{array}$ & Prevalence & $\begin{array}{c}\text { SatScan } \\
\text { cluster }\end{array}$ \\
\hline ARENC & 1 & 2 & 17 & 0 & 0.000 & 1 \\
\hline BAILLE & 2 & 5 & 1 & 0 & 0.000 & \\
\hline $\begin{array}{l}\text { BELLE DE } \\
\text { MAI }\end{array}$ & 3 & 3 & 20 & 1 & 0.050 & 1 \\
\hline BELSUNCE & 4 & 1 & 8 & 0 & 0.000 & \\
\hline BOMPARD & 5 & 7 & 0 & 0 & & \\
\hline $\begin{array}{c}\text { BON } \\
\text { SECOURS }\end{array}$ & 6 & 14 & 24 & 1 & 0.042 & 1 \\
\hline BONNEVEINE & 7 & 8 & 0 & 0 & & \\
\hline CARPIAGNE & 8 & 9 & 0 & 0 & & \\
\hline CASTELLANE & 9 & 6 & 2 & 1 & 0.500 & \\
\hline CHAPITRE & 10 & 1 & 1 & 0 & 0.000 & \\
\hline $\begin{array}{l}\text { CHATEAU- } \\
\text { GOMBERT }\end{array}$ & 11 & 13 & 0 & 0 & & \\
\hline $\begin{array}{c}\text { CHUTES } \\
\text { LAVIE }\end{array}$ & 12 & 4 & 0 & 0 & & 1 \\
\hline
\end{tabular}




\begin{tabular}{|c|c|c|c|c|c|c|}
\hline $\begin{array}{c}\text { CINQ } \\
\text { AVENUES }\end{array}$ & 13 & 4 & 0 & 0 & & \\
\hline ENDOUME & 14 & 7 & 0 & 0 & & \\
\hline EOURES & 15 & 11 & 0 & 0 & & \\
\hline $\begin{array}{l}\text { GRANDS } \\
\text { CARMES }\end{array}$ & 16 & 2 & 0 & 0 & & \\
\hline $\begin{array}{l}\text { HOTEL DE } \\
\text { VILLE }\end{array}$ & 17 & 2 & 2 & 0 & 0.000 & \\
\hline LA BARASSE & 18 & 11 & 0 & 0 & & \\
\hline $\begin{array}{c}\text { LA } \\
\text { BLANCARDE }\end{array}$ & 19 & 4 & 19 & 0 & 0.000 & \\
\hline $\begin{array}{c}\text { LA } \\
\text { CABUCELLE }\end{array}$ & 20 & 15 & 0 & 0 & & 1 \\
\hline LA CALADE & 21 & 15 & 0 & 0 & & 1 \\
\hline $\begin{array}{c}\text { LA } \\
\text { CAPELETTE }\end{array}$ & 22 & 10 & 0 & 0 & & \\
\hline $\begin{array}{c}\text { LA } \\
\text { CONCEPTION }\end{array}$ & 23 & 5 & 0 & 0 & & \\
\hline $\begin{array}{l}\text { LA CROIX } \\
\text { ROUGE }\end{array}$ & 24 & 13 & 0 & 0 & & \\
\hline LA DELORME & 25 & 15 & 0 & 0 & & 1 \\
\hline $\begin{array}{c}\text { LA } \\
\text { FOURRAGERE }\end{array}$ & 26 & 12 & 0 & 0 & & \\
\hline LA JOLIETTE & 27 & 2 & 30 & 1 & 0.033 & \\
\hline LA MILLIERE & 28 & 11 & 0 & 0 & & \\
\hline LA PANOUSE & 29 & 9 & 0 & 0 & & \\
\hline LA PLAGE & 30 & 8 & 0 & 0 & & \\
\hline LA POMME & 31 & 11 & 6 & 0 & 0.000 & \\
\hline LA ROSE & 32 & 13 & 17 & 0 & 0.000 & \\
\hline LA TIMONE & 33 & 10 & 1 & 0 & 0.000 & \\
\hline LA TREILLE & 34 & 11 & 0 & 0 & & \\
\hline $\begin{array}{c}\text { LA } \\
\text { VALBARELLE }\end{array}$ & 35 & 11 & 0 & 0 & & \\
\hline $\begin{array}{c}\text { LA } \\
\text { VALENTINE }\end{array}$ & 36 & 11 & 40 & 0 & 0.000 & \\
\hline LA VILLETTE & 37 & 3 & 0 & 0 & & 1 \\
\hline LA VISTE & 38 & 15 & 0 & 0 & & 1 \\
\hline LE CABOT & 39 & 9 & 0 & 0 & & \\
\hline LE CAMAS & 40 & 5 & 0 & 0 & & \\
\hline LE CANET & 41 & 14 & 2 & 0 & 0.000 & 1 \\
\hline LE MERLAN & 42 & 14 & 0 & 0 & & \\
\hline LE PHARO & 43 & 7 & 0 & 0 & & \\
\hline
\end{tabular}




\begin{tabular}{|c|c|c|c|c|c|c|}
\hline LE REDON & 44 & 9 & 0 & 0 & & \\
\hline LE ROUET & 45 & 8 & 1 & 0 & 0.000 & \\
\hline LES ACCATES & 46 & 11 & 0 & 0 & & \\
\hline $\begin{array}{c}\text { LES } \\
\text { ARNAVAUX }\end{array}$ & 47 & 14 & 0 & 0 & & 1 \\
\hline $\begin{array}{c}\text { LES } \\
\text { AYGALADES }\end{array}$ & 48 & 15 & 2 & 0 & 0.000 & \\
\hline $\begin{array}{c}\text { LES } \\
\text { BAUMETTES }\end{array}$ & 49 & 9 & 0 & 0 & & \\
\hline LES BORELS & 50 & 15 & 0 & 0 & & \\
\hline $\begin{array}{c}\text { LES } \\
\text { CAILLOLS }\end{array}$ & 51 & 12 & 0 & 0 & & \\
\hline LES CAMOINS & 52 & 11 & 0 & 0 & & \\
\hline $\begin{array}{c}\text { LES } \\
\text { CHARTREUX }\end{array}$ & 53 & 4 & 0 & 0 & & \\
\hline LES CROTTES & 54 & 15 & 39 & 1 & 0.026 & 1 \\
\hline LES GOUDES & 55 & 8 & 0 & 0 & & \\
\hline $\begin{array}{c}\text { LES } \\
\text { MEDECINS }\end{array}$ & 56 & 13 & 0 & 0 & & \\
\hline LES MOURETS & 57 & 13 & 0 & 0 & & \\
\hline LES OLIVES & 58 & 13 & 6 & 0 & 0.000 & \\
\hline LES RIAUX & 59 & 16 & 0 & 0 & & \\
\hline $\begin{array}{l}\text { LES TROIS } \\
\text { LUCS }\end{array}$ & 60 & 12 & 0 & 0 & & \\
\hline L'ESTAQUE & 61 & 16 & 1 & 0 & 0.000 & \\
\hline LODI & 62 & 6 & 0 & 0 & & \\
\hline MALPASSE & 63 & 13 & 0 & 0 & & 1 \\
\hline MAZARGUES & 64 & 9 & 0 & 0 & & \\
\hline MENPENTI & 65 & 10 & 0 & 0 & & \\
\hline MONTOLIVET & 66 & 12 & 3 & 0 & 0.000 & \\
\hline MONTREDON & 67 & 8 & 2 & 0 & 0.000 & \\
\hline NOAILLES & 68 & 1 & 8 & 0 & 0.000 & \\
\hline $\begin{array}{c}\text { NOTRE DAME } \\
\text { DU MONT }\end{array}$ & 69 & 6 & 10 & 0 & 0.000 & \\
\hline $\begin{array}{l}\text { NOTRE DAME } \\
\text { LIMITE }\end{array}$ & 70 & 15 & 0 & 0 & & \\
\hline OPERA & 71 & 1 & 3 & 0 & 0.000 & \\
\hline $\begin{array}{l}\text { PALAIS DE } \\
\text { JUSTICE }\end{array}$ & 72 & 6 & 0 & 0 & & \\
\hline PALAMA & 73 & 13 & 0 & 0 & & \\
\hline PERIER & 74 & 8 & 0 & 0 & & \\
\hline
\end{tabular}




\begin{tabular}{|c|c|c|c|c|c|c|}
\hline $\begin{array}{l}\text { POINTE } \\
\text { ROUGE }\end{array}$ & 75 & 8 & 1 & 0 & 0.000 & \\
\hline $\begin{array}{l}\text { PONT DE } \\
\text { VIVAUX }\end{array}$ & 76 & 10 & 0 & 0 & & \\
\hline PREFECTURE & 77 & 6 & 2 & 0 & 0.000 & \\
\hline $\begin{array}{l}\text { ROUCAS } \\
\text { BLANC }\end{array}$ & 78 & 7 & 0 & 0 & & \\
\hline $\begin{array}{l}\text { SAINT } \\
\text { ANDRE }\end{array}$ & 79 & 16 & 2 & 1 & 0.500 & 1 \\
\hline $\begin{array}{c}\text { SAINT } \\
\text { ANTOINE }\end{array}$ & 80 & 15 & 5 & 0 & 0.000 & \\
\hline $\begin{array}{c}\text { SAINT } \\
\text { BARNABE }\end{array}$ & 81 & 12 & 0 & 0 & & \\
\hline $\begin{array}{c}\text { SAINT } \\
\text { BARTHELEMY } \\
\end{array}$ & 82 & 14 & 0 & 0 & & 1 \\
\hline $\begin{array}{c}\text { SAINT } \\
\text { CHARLES }\end{array}$ & 83 & 1 & 10 & 0 & 0.000 & \\
\hline SAINT GINIEZ & 84 & 8 & 3 & 0 & 0.000 & \\
\hline SAINT HENRI & 85 & 16 & 0 & 0 & & \\
\hline $\begin{array}{l}\text { SAINT JEAN } \\
\text { DU DESERT }\end{array}$ & 86 & 12 & 0 & 0 & & \\
\hline $\begin{array}{c}\text { SAINT } \\
\text { JEROME }\end{array}$ & 87 & 13 & 0 & 0 & & 1 \\
\hline $\begin{array}{c}\text { SAINT } \\
\text { JOSEPH }\end{array}$ & 88 & 14 & 0 & 0 & & 1 \\
\hline SAINT JULIEN & 89 & 12 & 0 & 0 & & \\
\hline SAINT JUST & 90 & 13 & 5 & 1 & 0.200 & 1 \\
\hline $\begin{array}{c}\text { SAINT } \\
\text { LAMBERT }\end{array}$ & 91 & 7 & 0 & 0 & & \\
\hline $\begin{array}{c}\text { SAINT } \\
\text { LAZARE }\end{array}$ & 92 & 3 & 6 & 1 & 0.167 & 1 \\
\hline SAINT LOUIS & 93 & 15 & 16 & 1 & 0.063 & 1 \\
\hline SAINT LOUP & 94 & 10 & 0 & 0 & & \\
\hline $\begin{array}{c}\text { SAINT } \\
\text { MARCEL }\end{array}$ & 95 & 11 & 0 & 0 & & \\
\hline $\begin{array}{c}\text { SAINT } \\
\text { MAURONT }\end{array}$ & 96 & 3 & 36 & 1 & 0.028 & 1 \\
\hline SAINT MENET & 97 & 11 & 7 & 0 & 0.000 & \\
\hline SAINT MITRE & 98 & 13 & 0 & 0 & & \\
\hline SAINT PIERRE & 99 & 5 & 2 & 0 & 0.000 & \\
\hline SAINT TRONC & 100 & 10 & 0 & 0 & & \\
\hline
\end{tabular}




\begin{tabular}{|c|c|c|c|c|c|c|}
\hline $\begin{array}{c}\text { SAINT } \\
\text { VICTOR }\end{array}$ & 101 & 7 & 0 & 0 & & \\
\hline $\begin{array}{l}\text { SAINTE } \\
\text { ANNE }\end{array}$ & 102 & 8 & 0 & 0 & & \\
\hline $\begin{array}{c}\text { SAINTE } \\
\text { MARGUERITE }\end{array}$ & 103 & 9 & 0 & 0 & & \\
\hline $\begin{array}{l}\text { SAINTE } \\
\text { MARTHE }\end{array}$ & 104 & 14 & 1 & 0 & 0.000 & 1 \\
\hline SORMIOU & 105 & 9 & 0 & 0 & & \\
\hline THIERS & 106 & 1 & 16 & 0 & 0.000 & \\
\hline VAUBAN & 107 & 6 & 0 & 0 & & \\
\hline VAUFREGES & 108 & 9 & 0 & 0 & & \\
\hline VERDURON & 109 & 15 & 0 & 0 & & \\
\hline $\begin{array}{c}\text { VIEILLE } \\
\text { CHAPELLE }\end{array}$ & 110 & 8 & 0 & 0 & & \\
\hline
\end{tabular}

Table B2. Number of tests performed, Number of positive tests, prevalence and cluster number for the second campaign.

\begin{tabular}{|c|c|c|c|c|c|c|}
\hline Neighborhood & $\begin{array}{l}\text { Neighborhood } \\
\text { Number }\end{array}$ & District & $\begin{array}{c}\text { Number of } \\
\text { tests }\end{array}$ & $\begin{array}{c}\text { Positif } \\
\text { test } \\
\text { number }\end{array}$ & Prevalence & SatScan cluster \\
\hline ARENC & 1 & 2 & 13 & 2 & 0.154 & \\
\hline BAILLE & 2 & 5 & 0 & 0 & & 2 \\
\hline $\begin{array}{c}\text { BELLE DE } \\
\text { MAI }\end{array}$ & 3 & 3 & 16 & 2 & 0.125 & \\
\hline BELSUNCE & 4 & 1 & 39 & 2 & 0.051 & \\
\hline BOMPARD & 5 & 7 & 0 & 0 & & 1 \\
\hline $\begin{array}{c}\text { BON } \\
\text { SECOURS }\end{array}$ & 6 & 14 & 33 & 2 & 0.061 & \\
\hline BONNEVEINE & 7 & 8 & 0 & 0 & & \\
\hline CARPIAGNE & 8 & 9 & 0 & 0 & & \\
\hline CASTELLANE & 9 & 6 & 0 & 0 & & \\
\hline CHAPITRE & 10 & 1 & 35 & 3 & 0.086 & \\
\hline $\begin{array}{l}\text { CHATEAU- } \\
\text { GOMBERT }\end{array}$ & 11 & 13 & 0 & 0 & & \\
\hline $\begin{array}{l}\text { CHUTES } \\
\text { LAVIE }\end{array}$ & 12 & 4 & 0 & 0 & & \\
\hline $\begin{array}{c}\text { CINQ } \\
\text { AVENUES }\end{array}$ & 13 & 4 & 4 & 1 & 0.250 & 2 \\
\hline ENDOUME & 14 & 7 & 0 & 0 & & 1 \\
\hline
\end{tabular}




\begin{tabular}{|c|c|c|c|c|c|c|}
\hline EOURES & 15 & 11 & 0 & 0 & & \\
\hline $\begin{array}{l}\text { GRANDS } \\
\text { CARMES }\end{array}$ & 16 & 2 & 0 & 0 & & \\
\hline $\begin{array}{l}\text { HOTEL DE } \\
\text { VILLE }\end{array}$ & 17 & 2 & 1 & 1 & 1.000 & 1 \\
\hline LA BARASSE & 18 & 11 & 0 & 0 & & \\
\hline $\begin{array}{c}\text { LA } \\
\text { BLANCARDE }\end{array}$ & 19 & 4 & 0 & 0 & & 2 \\
\hline $\begin{array}{c}\text { LA } \\
\text { CABUCELLE }\end{array}$ & 20 & 15 & 0 & 0 & & \\
\hline LA CALADE & 21 & 15 & 17 & 1 & 0.059 & \\
\hline $\begin{array}{c}\text { LA } \\
\text { CAPELETTE }\end{array}$ & 22 & 10 & 1 & 1 & 1.000 & 2 \\
\hline $\begin{array}{c}\text { LA } \\
\text { CONCEPTION }\end{array}$ & 23 & 5 & 0 & 0 & & 2 \\
\hline $\begin{array}{l}\text { LA CROIX } \\
\text { ROUGE }\end{array}$ & 24 & 13 & 0 & 0 & & \\
\hline LA DELORME & 25 & 15 & 0 & 0 & & \\
\hline $\begin{array}{c}\text { LA } \\
\text { FOURRAGERE }\end{array}$ & 26 & 12 & 0 & 0 & & 2 \\
\hline LA JOLIETTE & 27 & 2 & 75 & 3 & 0.040 & \\
\hline LA MILLIERE & 28 & 11 & 0 & 0 & & \\
\hline LA PANOUSE & 29 & 9 & 0 & 0 & & \\
\hline LA PLAGE & 30 & 8 & 0 & 0 & & \\
\hline LA POMME & 31 & 11 & 2 & 1 & 0.500 & 2 \\
\hline LA ROSE & 32 & 13 & 23 & 2 & 0.087 & \\
\hline LA TIMONE & 33 & 10 & 0 & 0 & & 2 \\
\hline LA TREILLE & 34 & 11 & 0 & 0 & & \\
\hline $\begin{array}{c}\text { LA } \\
\text { VALBARELLE }\end{array}$ & 35 & 11 & 0 & 0 & & \\
\hline $\begin{array}{c}\text { LA } \\
\text { VALENTINE }\end{array}$ & 36 & 11 & 30 & 2 & 0.067 & \\
\hline LA VILLETTE & 37 & 3 & 5 & 2 & 0.400 & 3 \\
\hline LA VISTE & 38 & 15 & 0 & 0 & & 3 \\
\hline LE CABOT & 39 & 9 & 0 & 0 & & \\
\hline LE CAMAS & 40 & 5 & 1 & 1 & 1.000 & 2 \\
\hline LE CANET & 41 & 14 & 2 & 1 & 0.500 & \\
\hline LE MERLAN & 42 & 14 & 0 & 0 & & \\
\hline LE PHARO & 43 & 7 & 1 & 1 & 1.000 & 1 \\
\hline LE REDON & 44 & 9 & 0 & 0 & & \\
\hline LE ROUET & 45 & 8 & 10 & 1 & 0.100 & \\
\hline LES ACCATES & 46 & 11 & 0 & 0 & & \\
\hline
\end{tabular}




\begin{tabular}{|c|c|c|c|c|c|c|}
\hline $\begin{array}{c}\text { LES } \\
\text { ARNAVAUX } \\
\end{array}$ & 47 & 14 & 0 & 0 & & \\
\hline $\begin{array}{c}\text { LES } \\
\text { AYGALADES }\end{array}$ & 48 & 15 & 0 & 0 & & 3 \\
\hline $\begin{array}{c}\text { LES } \\
\text { BAUMETTES }\end{array}$ & 49 & 9 & 0 & 0 & & \\
\hline LES BORELS & 50 & 15 & 2 & 1 & 0.500 & 3 \\
\hline $\begin{array}{c}\text { LES } \\
\text { CAILLOLS }\end{array}$ & 51 & 12 & 0 & 0 & & 2 \\
\hline LES CAMOINS & 52 & 11 & 0 & 0 & & \\
\hline $\begin{array}{c}\text { LES } \\
\text { CHARTREUX }\end{array}$ & 53 & 4 & 2 & 1 & 0.500 & 2 \\
\hline LES CROTTES & 54 & 15 & 62 & 2 & 0.032 & \\
\hline LES GOUDES & 55 & 8 & 0 & 0 & & \\
\hline $\begin{array}{c}\text { LES } \\
\text { MEDECINS }\end{array}$ & 56 & 13 & 0 & 0 & & \\
\hline LES MOURETS & 57 & 13 & 0 & 0 & & \\
\hline LES OLIVES & 58 & 13 & 19 & 3 & 0.158 & \\
\hline LES RIAUX & 59 & 16 & 0 & 0 & & \\
\hline $\begin{array}{c}\text { LES TROIS } \\
\text { LUCS }\end{array}$ & 60 & 12 & 0 & 0 & & \\
\hline L'ESTAQUE & 61 & 16 & 32 & 2 & 0.063 & \\
\hline LODI & 62 & 6 & 0 & 0 & & \\
\hline MALPASSE & 63 & 13 & 0 & 0 & & \\
\hline MAZARGUES & 64 & 9 & 0 & 0 & & \\
\hline MENPENTI & 65 & 10 & 0 & 0 & & \\
\hline MONTOLIVET & 66 & 12 & 6 & 2 & 0.333 & 2 \\
\hline MONTREDON & 67 & 8 & 0 & 0 & & \\
\hline NOAILLES & 68 & 1 & 13 & 2 & 0.154 & \\
\hline $\begin{array}{c}\text { NOTRE DAME } \\
\text { DU MONT }\end{array}$ & 69 & 6 & 21 & 2 & 0.095 & \\
\hline $\begin{array}{l}\text { NOTRE DAME } \\
\text { LIMITE }\end{array}$ & 70 & 15 & 0 & 0 & & \\
\hline OPERA & 71 & 1 & 2 & 1 & 0.500 & \\
\hline $\begin{array}{l}\text { PALAIS DE } \\
\text { JUSTICE }\end{array}$ & 72 & 6 & 0 & 0 & & \\
\hline PALAMA & 73 & 13 & 0 & 0 & & \\
\hline PERIER & 74 & 8 & 0 & 0 & & \\
\hline $\begin{array}{l}\text { POINTE } \\
\text { ROUGE }\end{array}$ & 75 & 8 & 0 & 0 & & \\
\hline $\begin{array}{l}\text { PONT DE } \\
\text { VIVAUX }\end{array}$ & 76 & 10 & 0 & 0 & & 2 \\
\hline
\end{tabular}




\begin{tabular}{|c|c|c|c|c|c|c|}
\hline PREFECTURE & 77 & 6 & 8 & 2 & 0.250 & \\
\hline $\begin{array}{l}\text { ROUCAS } \\
\text { BLANC }\end{array}$ & 78 & 7 & 0 & 0 & & \\
\hline $\begin{array}{l}\text { SAINT } \\
\text { ANDRE }\end{array}$ & 79 & 16 & 11 & 3 & 0.273 & 3 \\
\hline $\begin{array}{c}\text { SAINT } \\
\text { ANTOINE }\end{array}$ & 80 & 15 & 2 & 1 & 0.500 & 3 \\
\hline $\begin{array}{c}\text { SAINT } \\
\text { BARNABE }\end{array}$ & 81 & 12 & 0 & 0 & & 2 \\
\hline $\begin{array}{c}\text { SAINT } \\
\text { BARTHELEMY }\end{array}$ & 82 & 14 & 6 & 1 & 0.167 & \\
\hline $\begin{array}{c}\text { SAINT } \\
\text { CHARLES }\end{array}$ & 83 & 1 & 42 & 3 & 0.071 & \\
\hline SAINT GINIEZ & 84 & 8 & 0 & 0 & & \\
\hline SAINT HENRI & 85 & 16 & 1 & 1 & 1.000 & 3 \\
\hline $\begin{array}{l}\text { SAINT JEAN } \\
\text { DU DESERT }\end{array}$ & 86 & 12 & 0 & 0 & & 2 \\
\hline $\begin{array}{c}\text { SAINT } \\
\text { JEROME }\end{array}$ & 87 & 13 & 16 & 2 & 0.125 & \\
\hline $\begin{array}{l}\text { SAINT } \\
\text { JOSEPH }\end{array}$ & 88 & 14 & 0 & 0 & & \\
\hline SAINT JULIEN & 89 & 12 & 0 & 0 & & \\
\hline SAINT JUST & 90 & 13 & 12 & 2 & 0.167 & \\
\hline $\begin{array}{c}\text { SAINT } \\
\text { LAMBERT }\end{array}$ & 91 & 7 & 2 & 2 & 1.000 & 1 \\
\hline $\begin{array}{c}\text { SAINT } \\
\text { LAZARE }\end{array}$ & 92 & 3 & 15 & 2 & 0.133 & \\
\hline SAINT LOUIS & 93 & 15 & 4 & 2 & 0.500 & \\
\hline SAINT LOUP & 94 & 10 & 0 & 0 & & \\
\hline $\begin{array}{c}\text { SAINT } \\
\text { MARCEL }\end{array}$ & 95 & 11 & 0 & 0 & & \\
\hline $\begin{array}{c}\text { SAINT } \\
\text { MAURONT }\end{array}$ & 96 & 3 & 85 & 2 & 0.024 & \\
\hline SAINT MENET & 97 & 11 & 39 & 2 & 0.051 & \\
\hline SAINT MITRE & 98 & 13 & 0 & 0 & & \\
\hline SAINT PIERRE & 99 & 5 & 2 & 1 & 0.500 & 2 \\
\hline SAINT TRONC & 100 & 10 & 0 & 0 & & \\
\hline $\begin{array}{c}\text { SAINT } \\
\text { VICTOR }\end{array}$ & 101 & 7 & 1 & 1 & 1.000 & 1 \\
\hline $\begin{array}{l}\text { SAINTE } \\
\text { ANNE }\end{array}$ & 102 & 8 & 0 & 0 & & \\
\hline
\end{tabular}




\begin{tabular}{cccccc}
\hline $\begin{array}{c}\text { SAINTE } \\
\text { MARGUERITE }\end{array}$ & 103 & 9 & 0 & 0 & \\
\hline $\begin{array}{c}\text { SAINTE } \\
\text { MARTHE }\end{array}$ & 104 & 14 & 0 & 0 & \\
\hline SORMIOU & 105 & 9 & 0 & 0 & \\
\hline THIERS & 106 & 1 & 8 & 0.125 & \\
\hline VAUBAN & 107 & 6 & 0 & 0 & 3 \\
\hline VAUFREGES & 108 & 9 & 0 & 0 & \\
\hline VERDURON & 109 & 15 & 0 & 0 & \\
\hline VIEILLE & 110 & 8 & 0 & 0 & \\
CHAPELLE & & & & &
\end{tabular}

\section{References}

1. Cucinotta, D. and M. Vanelli, WHO declares COVID-19 a pandemic. Acta Bio Medica: Atenei Parmensis, 2020. 91(1): p. 157.

2. Dong, E., H. Du, and L. Gardner, An interactive web-based dashboard to track COVID-19 in real time. The Lancet infectious diseases, 2020. 20(5): p. 533-534.

3. Baggett, T.P. and J.M. Gaeta, COVID-19 and homelessness: when crises intersect. The Lancet Public Health, 2021. 6(4): p. e193-e194.

4. Loubiere S., M.E., Allaria C., Mosnier M., Allibert A., Ninove L., Bosetti T., Farnarier C., Hamouda I., Auquier P., Mosnier E., Tinland A. , Seroprevalence of SARS-CoV-2 antibodies among homeless people living rough, in shelters and squats: a large population-based study in France. PLOS One, 2021. 16(9).

5. $\quad$ Roederer, T., et al., Seroprevalence and risk factors of exposure to COVID-19 in homeless people in Paris, France: a cross-sectional study. The Lancet Public Health, 2021. 6(4): p. e202-e209.

6. Yoon, J.C., et al., COVID-19 Prevalence among People Experiencing Homelessness and Homelessness Service Staff during Early Community Transmission in Atlanta, Georgia, April-May 2020. Clinical infectious diseases: an official publication of the Infectious Diseases Society of America, 2020.

7. Nogrady, B., What the data say about asymptomatic COVID infections. Nature, 2020.

8. Nouvellet, P., et al., Reduction in mobility and COVID-19 transmission. Nature communications, 2021. 12(1): p. 1-9.

9. Kaufman, D.F., Canadian homeless mobilities: Tracing the inter-regional movements of At Home/Chez Soi participants. The Canadian Geographer/Le Géographe canadien, 2020.

10. Snow, D.A. and M. Mulcahy, Space, politics, and the survival strategies of the homeless. American Behavioral Scientist, 2001. 45(1): p. 149-169.

11. Warszawski, J., et al., En mai 2020, 4, 5\% de la population en France métropolitaine a développé des anticorps contre le SARSCoV-2. Premiers résultats de l'enquête nationale EpiCov. 2020.

12. insee. 2021; Available from: https://www.insee.fr/en/metadonnees/definition/c1523.

13. Grzegorczyk, A., Socio-spatial diversity of Marseille at the turn of the 21st century. Bulletin of Geography. Socio-economic series, 2012(17): p. 45-55.

14. Martin, M., 17\% des habitants vivent sous le seuil de pauvreté en 2012. 2015.

15. Amore, K., M. Baker, and P. Howden-Chapman, The ETHOS Definition and Classification of Homelessness: An Analysis. European Journal of Homelessness, 2011. 5(2): p. 19-37.

16. Mosnier, E., et al., A Covid-19 mobile outreach diagnosis team adapted to the needs of homeless people. 2021.

17. Fournier, P.-E., et al., Contribution of VitaPCR SARS-CoV-2 to the emergency diagnosis of COVID-19. Journal of Clinical Virology, 2020. 133: p. 104682.

18. Team, R.C., R: A language and environment for statistical computing. Version 4.0. 2 (Taking Off Again). R Foundation for Statistical Computing, Vienna, Austria, 2020.

19. Team, Q.D., QGIS geographic information system. Open source geospatial foundation project, 2016.

20. Van Buuren, S. and K. Groothuis-Oudshoorn, mice: Multivariate imputation by chained equations in R. Journal of statistical software, 2011. 45(1): p. 1-67.

21. De Leeuw, J. and J. Van Rijckevorsel, HOMALS and PRINCALS-Some generalizations of principal components analysis. Data analysis and informatics, 1980. 2: p. 231-42.

22. Thioulouse, J. and S. Dray, Interactive multivariate data analysis in $R$ with the ade4 and ade4TkGUI packages. Journal of Statistical Software, 2007. 22(5): p. 1-14. 
23. Kiers, H.A., Simple structure in component analysis techniques for mixtures of qualitative and quantitative variables. Psychometrika, 1991. 56(2): p. 197-212.

24. Hotelling, H., Analysis of a complex of statistical variables with principal components. J. Educ. Psy., 1933. 24: p. 498-520.

25. Allaire, J., et al., networkD3: D3 javascript network graphs from R. R package version 0.4, 2017.

26. Kulldorff, M., SaTScan user guide for version 9.0. 2010.

27. Badr, H.S., et al., Association between mobility patterns and COVID-19 transmission in the USA: a mathematical modelling study. The Lancet Infectious Diseases, 2020. 20(11): p. 1247-1254.

28. Mosnier, E., et al., Facteurs associés à l'infection par le SARS-CoV-2, étude de cohorte de personnes en situation de sans-abrisme. Infectious Diseases Now, 2021. 51(5): p. S58.

29. Tinland, A., et al., Effectiveness of a housing support team intervention with a recovery-oriented approach on hospital and emergency department use by homeless people with severe mental illness: a randomised controlled trial. Epidemiology and psychiatric sciences, 2020. 29.

30. Aubry, T., et al., A multiple-city RCT of housing first with assertive community treatment for homeless Canadians with serious mental illness. Psychiatric services, 2016. 67(3): p. 275-281.

31. Šimon, M., et al., Activity spaces of homeless men and women measured by GPS tracking data: A comparative analysis of Prague and Pilsen. Cities, 2019. 86: p. 145-153.

32. Allaria, C., et al., "Locked down outside": Perception of hazard and health resources in COVID-19 epidemic context among homeless people. SSM-population health, 2021: p. 100829.

33. JORF, Ordonnance $n^{\circ} 2020-331$ du 25 mars 2020 relative au prolongement de la trêve hivernale. 2020: JORF $n^{\circ} 0074$ du 26 mars 2020. 